\title{
Research on the High Quality Development of Private Enterprises in Hebei Province based on Questionnaire Survey
}

\author{
Jingyuan Han \\ School of Economics and Management \\ Hebei University of Science and Technology \\ Shijiazhuang, Hebei, China \\ 13503332101@163.com
}

\author{
Caili Feng \\ School of Economics and Management \\ Hebei University of Science and Technology \\ Shijiazhuang, Hebei, China \\ 1156134940@qq.com
}

\begin{abstract}
Private enterprises in Hebei province play an important role in promoting the economic development, creating tax revenue and absorbing employment, therefore, it is of great significance to understand and grasp the high quality development of private enterprises for the economic development of our province and the formulation of relevant policies. With the purpose of conducting quantitative analysis on the high quality development of private enterprises in Hebei province, a questionnaires survey is carried out and 375 valid questionnaires are withdrawn, and based on the summary data, this paper makes an in-depth discussion on the high-quality development of private enterprises and puts forward reasonable suggestions.
\end{abstract}

Keywords-Private enterprise; High quality development; Private economy; Development

\section{INTRODUCTION}

Since the reform and opening up 40 years ago, the state has continuously increased support for private enterprises, and private enterprises have developed rapidly. The proportion of GDP created by the private economy has grown rapidly from $1 \%$ in the early stage of reform and opening up to more than $50 \%$ in 2015 . In 2016 , the added value of private economy in Hebei province accounted for $67.8 \%$ of the province's GDP, which shows that the contribution of private enterprises to our province's economy can't be ignored. In addition, the cash flow of the private economy also increased greatly[1].The number of employees in private enterprises in Hebei province increased from 15.09 million in 2010 to 2,177 in 2016 . The number of employees in private enterprises has increased substantially. As an important carrier of employment, private enterprises have made outstanding contributions to social stability.

At present, private enterprises in Hebei province are an important part of the market economy. It has become an important force in promoting China's economic growth[2]. They play an important role in promoting the economic development of the province, creating tax revenue and solving problems related to employment[3].High-quality development is an important part of president $\mathrm{Xi}$ 's socialist economic thinking with Chinese characteristics in the new era. Now, China's economy has turned from a stage of rapid growth to a stage of high-quality development Therefore, understanding the basic situation of private enterprises in Hebei province in promoting high-quality development is of great significance to the economic development and policy formulation of Hebei province.

In order to understand the basic situation, main practices, difficulties and suggestions of private enterprises in Hebei Province in promoting high-quality development, the investigation team has formulated a questionnaire on the high-quality development of private enterprises in Hebei Province in accordance with the deployment and requirements of the All-China Federation of Industry and Commerce. The survey retrieved 375 valid questionnaires from private enterprises in the province. The basic information of the respondents is shown in Table I.

TABLE I BASIC SitUATION OF THE QUESTIONNAIRE TARGETS OF PRIVATE ENTERPRISES

\begin{tabular}{l|l|l|l|l}
\hline $\begin{array}{l}\text { Main Business Income in 2017 } \\
\text { (Ten million yuan) }\end{array}$ & $\begin{array}{l}\text { Less } \\
\text { than 2 }\end{array}$ & $2-10$ & $10-100$ & $\begin{array}{l}\text { More than } \\
100\end{array}$ \\
\hline Proportion (\%) & 36.5 & 33.6 & 22.4 & 7.5 \\
\hline
\end{tabular}

II. RESEARCH ON THE RESULTS OF QUESTIONNAIRE ABOUT Private ENTERPRISES IN HEBEI PROVINCE

\section{A. Introduction of private enterprises in research and development}

In the questionnaire, the enterprise's $R \& D$ situation includes three aspects: the proportion of $R \& D$ personnel in the total number of employees; the proportion of R\&D expenses in the main business income in 2017; the main technical sources of the enterprise. The data of the first two indexes are shown in table II and table III. It can be seen from the data that private enterprises' investment in R\&D personnel still needs to be improved. Most private enterprises have a low proportion of investment in R\&D costs and a small number of patents. According to the summary results of multiple choice questions on the sources of technology of enterprises, independent development and talent introduction are the two most important methods, accounting for $53.1 \%$ and $44.5 \%$ of enterprises respectively. 
TABLE II The Proportion OF R\&D Personnel In The Total NUMBER OF EMPLOYEES

\begin{tabular}{ll|l|l|l|l}
\hline $\begin{array}{l}\text { The proportion of R\&D } \\
\text { personnel (\%) }\end{array}$ & $\begin{array}{l}\text { Less than } \\
5\end{array}$ & $5-20$ & $20-50$ & $\begin{array}{l}\text { More than } \\
50\end{array}$ \\
\hline Proportion(\%) & 47.5 & 37.3 & 12.5 & 2.7 \\
\hline
\end{tabular}

TABLE III The Proportion OF R\&D Expenses In The MaIN BUSINESS INCOME IN 2017

\begin{tabular}{ll|l|l|l|l}
\hline $\begin{array}{l}\text { The proportion of R\&D } \\
\text { expenses (\%) }\end{array}$ & $\begin{array}{l}\text { Less than } \\
1\end{array}$ & $1-5$ & $5-15$ & $\begin{array}{l}\text { More than } \\
15\end{array}$ \\
\hline Proportion(\%) & 29.3 & 44.5 & 16.5 & 9.6 \\
\hline
\end{tabular}

$B$. The relevant information about the quality brand of the enterprise

In the questionnaire, the questions about the quality brand of the enterprise are divided into four aspects: the number of famous trademarks at or above the provincial level; the proportion of the income of self-owned brands in the main business income in 2017; the product quality management system certification passed; the product quality control measures taken. The data of the first two indexes are shown in table IV and table V. According to the questionnaire, more than $70 \%$ of the surveyed enterprises have passed various forms of product quality management system certification. Among them, enterprises that have passed ISO series quality certification or 3C certification account for the highest proportion. According to the questionnaire results, quality cost management is the most common product quality control measures adopted by $51.5 \%$ of enterprises, followed by quality risk and control and quality online monitoring. In general, the surveyed enterprises have taken different measures to control product quality.

TABLE IV THE NUMBER OF FAMOUS TRADEMARKS AT OR ABOVE THE PROVINCIAL LEVEL

\begin{tabular}{l|l|l|l|l}
\hline $\begin{array}{l}\text { The number of famous trademarks } \\
\text { (piece) }\end{array}$ & 0 & $1-5$ & $5-10$ & $\begin{array}{l}\text { More than } \\
10\end{array}$ \\
\hline Proportion(\%) & 52.3 & 41.4 & 3.7 & 2.9 \\
\hline
\end{tabular}

TABLE V THE PROPORTION OF THE INCOME OF SELF-OWNED BRANDS IN THE MAIN BUSINESS INCOME IN 2017

\begin{tabular}{l|l|l|l}
\hline $\begin{array}{l}\text { The proportion of the income of } \\
\text { self-owned brands (\%) }\end{array}$ & $\begin{array}{l}\text { Less than } \\
20\end{array}$ & $\begin{array}{l}\text { 20-50 } \\
50\end{array}$ \\
\hline Proportion(\%) & 48.3 & 15.7 & 36 \\
\hline
\end{tabular}

\section{Internal management of the enterprise}

The majority of surveyed enterprises believe that they have better internal operation and management level or above in the same industry, accounting for $88.6 \%$. $11.2 \%$ of the enterprises think their operation and management level is average, and only $0.3 \%$ of enterprises think that their management level is poor in the same industry.

\section{The main results of the enterprise through "going out"}

Improving enterprise management level, establishing marketing network and acquiring brand, technology, talent and other strategic elements are the most important results obtained by the surveyed enterprises through "going global", accounting for $37.1 \%, 36.3 \%$ and $26.9 \%$, respectively. In addition, there are $23.5 \%$ of enterprises have not "going out".

\section{E. Green development of the enterprise}

Among the surveyed enterprises, improving the environmental protection performance of existing products and developing new environmental protection products are the most important measures taken by enterprises in the production of green products, accounting for $49.3 \%$ and $36 \%$, respectively, reflecting that enterprises pay more attention to the green development of products. In addition, the establishment of green supply chain and the transformation to low pollution and low energy consumption industries are also important measures taken by enterprises.

\section{F. Assessment of the business environment in the region}

As can be seen from the figure, $38.7 \%$ of the surveyed enterprises rated the business environment of this region as good, while more than $60 \%$ rated the business environment as good or average. To some extent, this reflects that the business environment of private enterprises still has room for further improvement.

\section{ANALysis OF THE DEVElopment QuALITY of PRIVATE ENTERPRISES}

According to the analysis of questionnaire data, the characteristics of private enterprises in our province in the high-quality development are shown as follows.

\section{A. Enterprise innovation research and development investment is insufficient, the brand construction level is low}

Enterprises' insufficient investment in innovation and $R \& D$ is reflected in the following aspects. First, the proportion of enterprise R\&D personnel is low; Second, enterprises invest less in research and development; Third, the number of invention patents owned by enterprises is small.

The low level of enterprise brand building is reflected in the following aspects: first, the enterprise lacks representative independent brand products, and more than $50 \%$ of the enterprises do not have famous trademarks at or above the provincial level; Second, the enterprise's independent brand product income accounts for a low proportion of the main business income; Third, the enterprise's production quality management consciousness is insufficient.

Innovation and R\&D are the driving force of enterprise development. The lack of investment in innovation and research and development seriously restricts the development of private enterprises and makes it difficult for them to reach the leading level of technology.

In addition, brand building is an important way to improve the core competitiveness of private enterprises. The establishment of a brand can greatly expand the market share and profit space of enterprises, which is of great value to the development of private enterprises.

\section{B. Positive performance of enterprise management}

Most enterprises believe that they have a high level of internal management in the same industry. They believe that they can take various measures to optimize enterprise management, such as establishing development plans, optimizing organizational structure and establishing and 
improving internal management rules and regulations, and strengthen the construction of staff through various forms. A higher level of management can enhance the operation efficiency of an enterprise, give the enterprise a clear direction of development, and enable every employee to give full play to their potential, so as to provide customers with satisfactory products and services.

Good management level is the internal power of the development of private enterprises. Effective management can improve the efficiency of enterprises and fully mobilize the enthusiasm of employees, which is of great significance to the development of enterprises.

\section{The business environment needs to be improved}

A good business environment is attractive, competitive, creative and driving force. Optimizing the business environment is an important basis for promoting high-quality development of private enterprises, which directly affects the quality and speed of economic development in Hebei province. A good business environment is conducive to attracting capital, talents, technology and other development elements and stimulating the vitality of market players.

The results of the questionnaire show that the proportion of enterprises with good business environment evaluation in this region is not high, which reflects that the business environment of private enterprises still has room for further optimization and improvement.

\section{Suggestions to Promote High Quality DEVELOPMENT OF PRIVATE ENTERPRISES}

A. Promoting industry-university-research cooperation with enterprises as the main body, and encouraging scientific and technological innovation activities to face the main battlefields of economic development

As an important force closely combining science and technology with economy, enterprises should become the subjects of technological innovation decision-making, R\&D investment, scientific research organization and achievement transformation. Therefore, promoting industry-university-research cooperation with enterprises as the main body is of great significance to the development of private economy in Hebei province. Therefore, the following Suggestions are proposed in this paper.

First, we should encourage the establishment of market-oriented information service institutions for scientific and technological achievements based on "Internet plus". This institution enables the market to play an important role in the transformation of scientific and technological achievements and improves work efficiency. By means of information and communication technology, cloud computing, Internet platform and other means, this institution timely, systematically and comprehensively shares the scientific and technological innovation achievements (patents), professional talent teams and other information of various scientific research institutes and universities and the technical demand information of enterprises, so as to open up a convenient channel for scientific and technological innovation and economic transfer and transformation.
Second, we can bring the "mobile innovation team" of colleges and universities into the mode of industry-university-research cooperation innovation of enterprises. The government can guide and organize the related disciplines of colleges and universities to set up a "mobile innovation" team. Then, with the establishment of research institutions as the platform and projects as the carrier the team will break through the traditional mode of industry-university-research cooperation and be brought into the enterprise flexibly to provide targeted services for private enterprises. On the one hand, it can effectively change the current situation of shortage of professional theories and technical management talents, weak ability of technological innovation, lack of independent intellectual property rights and brands, and low technical content of products. On the other hand, professional and technical teams of colleges and universities can truly enter private enterprises. In response to the actual situation and needs of enterprises, they carry out the application and promotion of new technologies, or develop new products adapted to the market for private enterprises.

\section{B. Improving the comprehensive evaluation mechanism for the utilization of resource factors and optimizing the business environment for private enterprises}

Resource elements play an indispensable role in the development of enterprises. Reasonable evaluation mechanism of resource elements is conducive to arousing the enthusiasm of enterprises. A good business environment is conducive to attracting capital, talents, technology and other development elements and stimulating the vitality of market players. Therefore, the following Suggestions are proposed in this paper.

First, we suggest that government departments formulate scientific evaluation methods to evaluate the output benefits (tax revenue, employment) of land occupied by enterprises, energy, environmental protection and other essential resources, and rank them according to industry classification. Then, according to the classification and ranking of industries, enterprises with high resource utilization efficiency will be rewarded. Enterprises with low resource utilization efficiency will be charged with differential electricity price, water price and urban land use tax, and relevant preferential policies will be cancelled.

Second, we will further relax market access for the private sector. We will establish a market access complaint mechanism for private enterprises, and gradually improve the mechanism for coordinating and resolving complaints in response to the unfair market access problems reflected by private enterprises.

Third, we will focus on the problem of non-responsibility and inaction on the part of cadres. First, we must actively carry out special rectification actions such as "not taking on responsibilities or doing nothing". Monthly notification, timely supervision and handling should be carried out to strengthen the implementation of rectification. We should take measures to punish those who have serious problems. Second, a number of negative cases should be exposed to guide education cadres to enhance their consciousness of responsibility. Finally, we should build a multi-level 
supervision system and broaden the sources of problem clues. The masses call inform against and mailbox inform against must treat seriously. Relevant departments regularly collect and sort out problems. At the same time, make use of the important advantages of scientific and technological supervision in the Internet era. We should fully rely on the government's Intranet, official website, WeChat and other public reporting telephone and Internet mailbox, and set up corresponding columns and platforms for accepting reports.

\section{CONCLUSIONS}

As an important part of the market economy in Hebei province, it is very important for private enterprises to solve the bottlenecks and problems in their development. Accelerating the high-quality development of private enterprises in Hebei province is an important link in building a strong economy and beautiful Hebei province in the new era The development of market economy depends on private enterprises. How to make private enterprises bigger and stronger is the key to the development of our province's economy.

Based on 375 valid questionnaires about the high-quality development of private enterprises in Hebei province, this paper summarizes the relevant situations of the high-quality development of private enterprises with specific data. The research found that the enterprise in $R \& D$ investment, brand building and other aspects of the existence of problems. On the basis of these problems, this paper puts forward the following Suggestions: first, deepen the industry-university-research cooperation with enterprises as the main body, and promote scientific and technological innovation activities to face the main battlefield of economic construction. This measure stimulates the vitality of enterprise innovation. Second, improve the comprehensive evaluation mechanism for the utilization of resources and factors and optimize the business environment for private enterprises. The implementation of these Suggestions will help the private enterprises in Hebei province break through the bottleneck and achieve high-quality development. Resource elements play an indispensable role in the development of enterprises. This measure can greatly improve the enterprise's enthusiasm. Rectification cadre is not assumed, do not act problem, can make each branch serves for the enterprise practically. This helps companies reflect their needs. The implementation of these measures will help private enterprises in hebei province break through the bottleneck and achieve high-quality development.

\section{REFERENCES}

[1] Huang Lianggang, Tang Desheng, Wu Rangsong. Improve the operating environment and promote the development of private economy[J]. Hubei social science, 1998(09),21+29.

[2] Tong Ling, Jin Zhaohuai. Thoughts and countermeasures on the scientific development of private economy in China[J]. Exploration of economic problems,2012(04),130-133.

[3] Liu Xianwei, Wen Fengan. Difficulties and Strategies of Promoting the High-quality Development of Private Economy in the New Era[J]. Reform,2018(09),5-14.

[4] Wang Yiming, Sun Xuegong, Liu Hongwei. Survey on the development of private economy in guizhouprovince $[\mathrm{J}]$. Macroeconomic management,2015(06),47-49.

[5] Ma Yong. Survey report on the current situation of private economy in Tibetan areas in sichuan province-- a case study of ganzi and aba[J]. NorthWest Minorities Research,2005(4),131-151.

[6] Lei Jiebin, Xie Zhiqing. Analysis of problems and countermeasures in the development of private economy in China at present[J]. Special Zone Economy,2010(02),141-142.

[7] Xiong Siyong, Qu Xiaoyi, Yang Ying, Yang Meng. Research on the development path and direction of private economyin suzhou[J]. Tianjin Science \& Technology, 2018(06), 12-19.

[8] Chen Yongjie. Analysis on the development of private economy in China in 2006[J]. China Industrial Economy, 2007(11),15-22. 